\title{
DEVELOPING A MODEL OF INDUSTRY-BASED PRACTICUM LEARNING
}

\author{
Bambang Sudarsono \\ Universitas Muhammadiyah Purworejo \\ bamz_salam@yahoo.com \\ Thomas Sukardi \\ Fakultas Teknik Universitas Negeri Yogyakarta \\ thomkar234@yahoo.co.id
}

\begin{abstract}
The study was to: (1) produce a practicum learning model that might be applied by the lecturers of Automotive Engineering Education Program as the center of Light Vehicle Engineering (LVE) Study Program prospective teachers in the vocational high schools (VHS); (2) identify the automotive industry-oriented competence aspects in practicum learning needed by the LVE Study Program prospective teachers in the VHS; (3) identify the degree of implementatibility of the practicum learning model that had been developed for the LVE Study program prospective teachers in the VHS; and (4) identify the effectiveness degree of the practicum learning model that had been developed for the LVE Study Program prospective teachers in the VHS. The model development in the study referred to the research and development model proposed by Richey and Klein. The research subjects were the students of Automotive Engineering Education Study Program Muhammadiyah University Purworejo. Then, the research objects were Toyota Magelang Company, the Daihatsu Armada Company and the Ultratune Company Gadjah Mada University. The results of the study show that: (1) the competency aspects developed in the P2BI Model for the students who refer the LVE Study Program prospective teachers include the affective aspect, the cognitive aspect and the psychomotor aspect; (2) the improvement of the affective, the cognitive and the psychomotor aspect has met the "Very Good" criteria; (3) the students' activities in the implementation of the P2BI Model Stages have been very good; and (4) the students' responses toward the P2BI Learning Model have been very positive.
\end{abstract}

Keywords: learning model, practicum learning, LVE Study Program prospective teachers

\section{PENGEMBANGAN MODEL PEMBELAJARAN PRAKTIK BERBASIS INDUSTRI}

\begin{abstract}
Abstrak
Tujuan penelitian ini adalah untuk: (1) menghasilkan model pembelajaran praktik yang dapat diterapkan oleh dosen pendidikan teknik otomotif sebagai penghasil calon guru SMK Program Keahlian Teknik Otomotif (PKTO), dan (2) mengetahui aspek-aspek kompetensi pada pembelajaran praktik yang dibutuhkan calon guru SMK PKTO. Model pengembangan dalam penelitian ini mengacu model research and development dari Richey and Klein. Subjek penelitian adalah mahasiswa Program Studi Pendidikan Teknik Otomotif Universitas Muhammadiyah Purworejo. Objek penelitian di PT. Toyota Magelang, PT. Daihastu Armada dan PT. Ultratune UGM. Hasil penelitian ini adalah sebagai berikut. (1) Aspek-aspek kompetensi yang dikembangkan pada model P2BI bagi mahasiswa calon guru SMK PKTO adalah aspek sikap,aspek pengetahuan dan aspek ketrampilan. (2) Peningkatan aspek sikap, pengetahuan dan ketrampilan dengan kriteria sangat baik. (3) Aktivitas mahasiswa dalam pelaksanaan tahapan-tahapan model P2BI sangat baik dan (4) Tanggapan mahasiswa terhadap model pembelajaran P2BI sangat positif.
\end{abstract}

Kata Kunci: model pembelajaran,pembelajaran praktik, calon guru SMK PKTO. 


\section{INTRODUCTION}

The problems regarding the vocational education up to date have still under consideration and should be resolved together. (Siriwat, 1995, pp. 41-44) in his speech in front the APEC (Asia Pacific Economic Cooperation) forum under the topic "Internationalization of Vocational Education" states that the members of APEC have been encountering the following vocational education problems: (1) the relationship among the industry, the trading sector, the state and the training and education institution has not been well established; (2) the technical and vocational teachers have still been lack of actual experiences in the related employment sector; (3) most of the vocational education curricula have still been theoretical and had some problems in drawing the connection between the theory and the practical application that will be necessary in the employment sector; (4) the vocational engineering education and training has been limited to the secondary educational system upward; (5) the vocational engineering education and training has not been able to improve the intensive program for the sake of improving the capacity of the existing labors; (6) the vocational teacher training programs have not been equipped with the teaching methods that focus to the improvement of engineering capability; (7) most of the vocational engineering curriculum have not been flexible and have been outdated and, in addition, the sources for improving the curriculum has been difficult to design; and (8) the practicum learning equipment and facilities in the schools and the vocational engineering universities have not been in accordance with the technological advancement in the industrial domains.

Looking at the vocational education problems that have been mentioned by Siriwat, the Indonesian government since 2004 has been taking several solutions in order to solve those problems. One of the solutions is changing and developing the proportion of senior high school units and vocational high school units. The strategic plan of the Department of National Education states that the proportion of senior high school units and vocational high school units in Indonesia will be expected to approach $70 \%$ to $30 \%$. As time goes by, the consideration toward the policy on the proportion of senior high school units and vocational high school units actually demands in-depth reasoning regarding the preparation, the implementation and overall impact toward the policy especially in terms of cost and teaching staff that should be prepared in order to overcome the increasing number of vocational high school units.

Teachers have been one of the important components in shaping the learning participants' characters and qualities. The teachers hold important role in the educational development, the one that has been implemented formally within the schools. The teachers have the duty of developing the curriculum, the learning sources, the facilities and the learning climate. Any efforts that have been performed in order to develop the educational quality will not provide significant contribution without being supported by the professional and well-qualified teachers.

The Law Number 14 Year 2005 regarding Teachers and Lecturers states that the main task of a teacher is to educate, to teach, to guide, to direct, to train, to assess and to evaluate the learning participants. The role of a teacher is very important within the process of educational interaction; as a result, a teacher's incapability to perform the educational interaction will negatively impact the quality and the development of the national life in the future. The statement strengthens a wrong impression that people who do not master the science of education might be regarded as a teacher as long as they understand the learning materials and the fact that teaching is merely a process of transferring the learning materials.

Walker (2013, p. 64) states that there are 12 characteristics that a teacher should possess in order to improve the educational interaction process namely: (1) a teacher should be ready before and during the learning process; (2) a teacher should have positive mind toward the students and the classroom condition; (3) a teacher should be able to provide high motivation toward the students; (4) a teacher should be creative in conducting the learning process; (5) a teacher should be just toward all students; (6) a teacher should have closed relationship with the students; (7) the most effective teacher will be the one who make the students feel 
accepted and comfortable within the classroom; (8) the most effective teacher will be the one who immediately ask for an apology in front of the students when he or she commits a mistake; (9) the most effective teachers will not take anything seriously and create an enjoyable learning process; (10) the most effective teacher will never humiliate the students; (11) the most effective teacher will not try to retaliate anything toward the students; and (12) the most effective teacher is the one that shows genuine attention toward the students' personal problems and the one that might have interaction with the students.

The statement by Walker provides a description that a teacher should not only deliver the learning materials but also direct and train the students' intellectual and psychomotor skill; in addition, a teacher should also motivate the students to have innovative and creative capacity and should take the responsibility of changing the learning participants' behaviors. According to Chauhan (2009, p. 4), "Teaching is the stimulation, guidance, direction and encouragement of learning." From the statement, we might infer that the professional tasks of a teacher demand the specialized capacities that are different than the other learning qualifications and there should be an optimal process of shaping and equipping the prospective teachers by the Education and Teaching Staff Institutions (LPTK, Lembaga Pendidik dan Tenaga Kependidikan).

The process of shaping and equipping the prospective teachers by the LPTK will be different based on the degree and the qualification of their skills and the same process also applies toward the vocational education teachers. The vocational education teachers have several different characteristics in comparison to the other teachers. Prosser \& Quigley $(1950$, p. 234) states that the vocational education teachers have the following characteristics: (1) being able to facilitate the tasks and the exercises through the manners, the methods and the machineries that are similar to the ones in the employment; (2) being able to train the students in internalizing the habits of thinking and working in accordance to the respective employment; (3) being able to shape the training experiences and the working habits as well as the repetitive thinking habit in accordance with the necessary skills in the employment; and (4) having experiences of being successful in implementing the knowledge and skills in working process and operation that they perform.

(Frisk, 2014, p. 11) states that the vocational education teachers should: (1) have the professional working experiences and master the expertise domain in terms of theory and practice; (2) have the strong professional skills in their respective domain; (3) regularly take participations in the development of employment demands; (4) teacher with learning alternatives according to the employment; (5) have actual knowledge in the employment and have the capacity to anticipate the demands of related competencies; and (6) meet the employment demand and plan and implement the educational process related to the employment and the working sectors.

In order to deal with the problems in meeting the needs and the quality of vocational high school teachers, several departments and study programs have been developed by the LPTK. One of such departments and study programs is the Automotive Engineering Study Program (PTO, Program Studi Pendidikan Teknik Otomotif). According to Arifin (2016), the PTO as a higher educational institution has the tasks and the functions of generating the well-qualified and professional graduates in the automotive domain both in the automotive engineering study program of vocational high schools and the automotive industry. On the other hand, based on the Government Regulation Number 8 Year 2012 Regarding the Criteria of Indonesian National Competency (PP Nomor 8 Tahun 2012 tentang KKNI), the graduate profiles of the PTO are as follows: (1) the teachers in the automotive engineering study program of vocational high schools; (2) the instructor of education and training in the automotive engineering educational institutions; (3) the instructor of education and training in the centers of automotive engineering education and training within the automotive industry; and (4) the designer of training programs in the automotive engineering education. In order to generate the profiles of well-qualified graduates, the implementation of education and training in the Automotive Engineering Study Program Education and Teaching Staff Institutions, or the LPTK PTO, should refer to the compe- 
tencies in the education and the non-education competencies, namely the competencies of vehicle maintenance and reparation.

Dharmaputra (2009) states that the vocational high school teachers, especially the ones in the Automotive Engineering Expertise Program (PKTO, Program Keahlian Teknik Otomotif) should meet several requirements namely mastering the automotive engineering competencies and having the automotive engineering basic competencies. In order to meet the prerequisites of the competent automotive engineering expertise program of vocational high school (SMK PKTO) teachers there should be supports from multiple parties and these supports are expected to help the process of shaping the prospective teaching staff that will be ready and competent in serving as the learning facilitators for the SMK PKTO students. For achieving the objectives in shaping the SMK PKTO teachers who are in line with the conditions of employment and industry, there should scientific coverage in terms of theory and practice, equipment and sufficient facilities.

Furthermore, Muhammadiyah (2013) states that the VHS teachers as a teacher of vocational subjects have an important role in generating the VHS graduates who will meet the needs and the demands of industrial domains. The productive teachers as the LPTK products nowadays still have multiple drawbacks in the knowledge toward the advanced technology; most of the productive teachers have not been able to set the pace with the advancement of knowledge and technology. The factors of productive teachers and professionalism have also been the variables that should be given attention when discussing the VHS graduates, the VHS teachers and the industrial domain. The advanced science as having been applied by the industrial domain might be associated to the practicum learning that will be provided to the university students or the prospective teachers and the SMK PKTO instructors since the criteria of the prospective teachers and the SMK PKTO instructors have not met the expectation, should be improved and demand more problem-solving actions. The practicum learning for the SMK PKTO teachers have been low and have not been supported by the sufficient practicum tools, the employment and the automotive industry.
The competencies of PTO graduates will be optimum if the learning process involves multiple components namely curriculum, lecturers, university students and other supporting facilities. According to Gunadi (2013), the LPTK as an institution that generates the teachers nowadays encounters multiple challenges in terms of generating the professional prospective teachers; in addition, the LPTK also encounters challenges provided by the government policies in relation to the teacher provision. The VHS prospective teachers are encountered by the outdated learning facilities in their campus and they are concerned that the outdated learning facilities will interrupt the mastery of productive teaching skills in the VHS within the near future. The prospective teacher-university students who have minimum working experiences in the industrial domain are concerned as well that they might lack of contemplation toward the actual employment. Therefore, the LPTK should establish partnership among the LPTK themselves, the schools and the industry. Based on the reference, it will be better if the learning components mentioned above should be well prepared in order to decrease the problems in the continuous learning process.

Looking at the problems that have been explained above, the improvement toward the learning practicum for the SMK PKTO prospective teachers by the Automotive Engineering Education Study Program should be the focus of the learning process implementation that emphasizes the mastery of fundamental skills and the appropriate working techniques and tools. In addition to the learning process that will be implemented in the campus, the learning process itself is expected to have orientation toward the automotive industry or the garage as the direction of practicum learning objectives implementation. The reason is that the university students might recognize, identify and understand the actual employment demanded by the automotive industry.

The process of practicum learning for the SMK PKTO prospective teachers involves the working activities in the automotive industry. The process of practicum learning is not only a matter of knowledge transfer from the lecturers to the students through a textual manner. Instead, each process of practicum 
learning should afford to deliver the university students or the SMK PKTO prospective teachers toward the mastery of industrialbased competencies, including the underlying values of knowledge and attitudes. Therefore, the practicum learning for the SMK PKTO prospective teachers are expected to not always be implemented in the classroom; instead, the practicum learning might always be implemented in the garage or the automotive industry.

According to Linehan (2008, p. 21), several work-based learning characteristics within the industry might be described as follows: (1) the learning materials are associated to the tasks in the working place; (2) the learning process is related to the issues that occur in the working place (the workbased learning is mostly associated to the very complex working issues namely: production, design or management); (3) the learning process is innovative (the work-based learning contains new matters/techniques or approaches that are repetitively designed in order to meet the new situations, to create multiple learning opportunities and to provide experiences in managing changes); (4) the learning process emphasized the practical aspects and the timeliness; (5) the learning process is independent (the learning process is conducted without any direct instructions (independent) and is responsible to ensure the learning quality from their learning activities; (6) the learning process is self-motivating; (7) the learning process is conducted by emphasizing the cooperation (implementing a learning process by means of cooperation will be effective among the people who have different roles and skills and such learning process will lead to the development of multiple personal skills and qualities); (8) the learning process improves the honesty and the responsibility by means of personal performance assessment; and (9) the learning process has the spirit of increasing the business, the company or the organization performance.

Several experts elaborate the appropriate model stages for the practicum learning of the SMK PKTO prospective teachers. According to Joyce, Weil, \& Calhoun (2009, p. 427), the practicum learning consists of five stages. The first stage is the Orientation. In this stage, the teacher starts constructing/ establishing the subject framework. The teacher delivers his or her expectations, explaines the existing tasks in the subject and determines the students' responsibilities. There are three aspects that become the requirements to achieve the objective namely: (a) the teacher elaborates the meaning of the subject and the performance stages in the practicum learning; (b) the teacher explains the contents of the subject and their association to the past experiences; and (c) the teacher discusses the learning procedures.

The second stage is the Presentation. In this stage, the teacher explains the new concepts or skills and provides demonstrations along with examples. If the existing materials are the new concepts, then the teacher should discuss the characteristics of the new concepts, the defining regulations and several examples. On the other hand, if the existing materials are the new skills then the teacher should deliver the steps for attaining the new skills along with the examples of each step. The teacher should transfer the information of the new materials or the new skills both in oral and in visual manner, so that the students might have and learn the visual representation. In addition, the teacher should also test the students in terms of new material or now skill information mastery before proceeding to the next stage.

The third stage is the Structured Practicum. In this stage, the teacher guides the students through the examples of practicum steps. Usually, the students implement the practicum in a group and then offer themselves to write down the answerrs. The most effective manner will be providing the practicum examples openly and transparently so that each student view how to accomplish the practicum stages. The role of the teacher in this stage is to provide feedback toward the students' responses both for strengthening the students' appropriate responses and for rectifying and directing the students toward the appropriate practicum performance.

The fourth stage is the Practicum under the Teacher's Guidance. In this stage, the teacher provides opportunities for the students to perform the practicum under their own capacity. The practicum under the teacher's guidance will ease the teacher in preparing and in developing the students' capacity and also in displaying the learning tasks. The stage is usually conducted by minimizing the num- 
ber and the type of errors that the students commit. The role of the teacher in this stage is to control the students' work and to provide the corrective feedback when necessary.

The fifth stage is the Independent Practicum. In this stage, the students perform the practicum in their own manner without any assistance and feedback from the teachers. The objective of the Independent Practicum is to provide new materials for ensuring and for testing the students' understanding toward the previous practicums. The Independent Practicum should be reviewed as soon as possible after the students have completed the overall process. The review should be conducted in order to identify and predict the students' level of accuracy (stable or labile) as well as to provide corrective feedback at the end of the practicum toward the demanding students. The activities of Independent Practicum might be conducted in a short period of time.

The learning stages proposed by Joyce et al. (2009, p. 242) has been supported by Leighbody \& Kidd $(1968$, p. 21) who state that in the practicum learning the educator (the lecturer) should implement four learning stages. The first stage is the Preparation Step. In the Preparation Step, the educator should prepare the methods, the tools or the materials and he or she should also prepare and design the equipment through the appropriate method. The most important aspects in this stage are triggering the students' attention, drawing the students' interest and motivation, elaborating the competencies that will be achieved, convincing that all of the tools/materials have been prepared, informing clearly what the students should do, explaining the job safety and arranging the working place of each student in order that they will not disturb one to another.

The second stage is the Presentation Step. The Presentation Steps is basically the stage in which the instructor makes use of the model or the actual object in order to present or to explain the steps in a process or a procedure by means of direct performance. The implementation of the stage is similar to the demonstration stage in the demonstration method. The sequences of the Presentation Step includes: explaining the objectives, checking whether the students have understood the technique/skills that will be demon- strated, explaining the new matters/tools that will be operated, describing the process and demonstrating the skills/process appropriately and within the normal time limit.

The third stage is the Application Step. The Application Step is the stage in which the students perform the practicum assignments that the instructor has provided. The activities of an instructor in the Application Step are namely: (a) monitoring the students carefully; (b) providing assistance to the students who have difficulties; (c) stopping the students' performance and correcting their performance if the students commit errors or mistakes; and (d) demonstrating and explaining again the difficult part if necessary.

The fourth stage is the Testing Step. In the Testing Step, the educator provides the performance test as the import stage in achieving the successful practicum learning. The evaluation might be conducted during the practicum or after the practicum has been ended. The evaluation toward the practicum process should be conducted during the practicum or after the practicum has been ended in order to provide the feedback for the students.

\section{METHOD}

The study made use of the Research and Development approach that aimed to develop a model of Industry-Based Practicum Learning for the Automotive Engineering Study Program (PKTO, Program Kejuruan Teknik Otomotif) Vocational High School Prospective Teachers, which would be abbreviated into P2BI (Pembelajaran Praktek Berbasis Industri). The research and development model in the study referred to the one developed by Richey \& Klein (2009, p. 8) with the following development stages: (1) model development; and (2) model validation (internal and external validation). The basic assumption of the development was that the study had been conducted in order to attaining the validity and the effectiveness of the model development, the process and the technique that had been new or that had been already in existence. The participants in the study were the designers, the evaluators, the learning participants and the instructors.

The development model by Richey \& Klein had been considered suitable and ap- 
propriate to implement in developing the learning model because the objective was not only to identify the implementation profiles or learning practices but also to develop the more effective and adaptable learning model in accordance to the actual demand and condition within the LPTK as the educating ground for the SMK PKTO prospective teachers.

The experimental design of the study was pursued by implementing the P2BI model into two job competencies in five rounds. The subjects of the model experiment were the fifth semester students from the Automotive Engineering Study Program Muhammadiyah University Purworejo who had the characteristics and who had been prepared to be the SMK PKTO prospective teachers.

Then, the site that had been selected for the P2BI model experiment was the automotive industry through the representativeness of Single Brand-Holder Agent (ATPM, Agen Tunggal Pemegang Merk) and the nonATPM garages. The selection of the experiment site had been considering the suggestions from the PTO lecturers and the SMK PKTO teachers. The study was conducted for about three months starting from September 2015 until January 2016.

The data gathering instruments within the study consisted of interview, practicum test assessment sheet, questionnaires and observation sheet. The interview was conducted in order to develop the model. On the other hand, the practicum test assessment sheet, the questionnaires and the observation sheet were distributed in order to identify the implementation level of the model and to test the model effectiveness.

The data in the study would be categorized into two types namely the qualitative data and the quantitative data. The qualitative data would be attained from the interview, while the quantitative data would be attained from the practicum test assessment sheet, the questionnaires and the observation sheet. Next, the qualitative data would be analyzed based on the content and the quantitative data would be analyzed by means of the descriptive statistics. For the indicators of the model effectiveness and implementation level, the researchers would refer to Table 1 and Table 2.
Table 1. The Criteria of Practicum Assessment and Students' Activities Assessment and Meaning

\begin{tabular}{ccc}
\hline $\begin{array}{c}\text { Assessment } \\
\text { Norms }\end{array}$ & Score Range & Criteria \\
\hline$X \geq \mu+1 . \beta$ & $\mathrm{X} \geq 3,00$ & $\begin{array}{c}\text { Very Good } \\
(\mathrm{SB}, \text { Sangat Baik) }\end{array}$ \\
$\mu+1 . \beta>X \geq \mu$ & $3,00>\mathrm{X} \geq 2,50$ & $\begin{array}{c}\text { Good } \\
(\mathrm{B}, \text { Baik) }\end{array}$ \\
$\mu>X \geq \mu-1 . \mathrm{B}$ & $2,50>\mathrm{X} \geq 2,00$ & $\begin{array}{c}\text { Less Good } \\
(\mathrm{K}, \text { Kurang Baik) } \\
\text { Poor }\end{array}$ \\
$X<\mu-1 \beta$ & $\mathrm{X}<2,00$ & $(\mathrm{~T}$, Tidak Baik) \\
\hline
\end{tabular}

Table 2. The Criteria of Response Questionnaires Assessment

\begin{tabular}{|c|c|c|}
\hline Formula & Range & Criteria \\
\hline$X>\mu+1,8 \beta$ & $X>4,08$ & $\begin{array}{c}\text { Strongly Agree } \\
\text { (SS, Sangat Setuju) }\end{array}$ \\
\hline$\mu+0,6 \beta<X \leq \mu+1,8 \beta$ & $3,36<\mathrm{X} \leq 4,08$ & $\begin{array}{c}\text { Agree } \\
(\mathrm{S}, \text { Setuju })\end{array}$ \\
\hline$\mu-0,6 \beta<X \leq \mu+0,6 \beta$ & $2,64<\mathrm{X} \leq 3,36$ & $\begin{array}{c}\text { Doubt } \\
(\mathrm{R}, \text { Ragu-Ragu })\end{array}$ \\
\hline $\boldsymbol{\mu}-1,8 \beta<X \leq \mu-0,6 \beta$ & $1,92<X \leq 2,64$ & $\begin{array}{c}\text { Disagree } \\
\text { (TS, Tidak Setuju) }\end{array}$ \\
\hline $\boldsymbol{X} \leq \boldsymbol{\mu}-1,8 \beta$ & $X \leq 1,92$ & $\begin{array}{c}\text { Strongly Disagree } \\
\text { (STS, Sangat Tidak } \\
\text { Setuju) }\end{array}$ \\
\hline
\end{tabular}

\section{RESULTS AND DISCUSSIONS}

The development in the study adopted the concept of developmental research by Richey and Klein (2009) in which the development study included the model development and the model validation. The model development was initiated by the needs assessment. The main objective of conducting the needs assessment was to attain information regarding the aspects of competence that should be possessed by the SMK PKTO prospective teachers. The description of the competence aspects would be elaborated in the Table 3.

After the model development had been conducted, the next stage would be the internal validation. The internal validation would be conducted through the FGD activities and the expert judgment/review. The FGD activities were conducted altogether with the learning experts, the vocational education experts, the automotive material experts, the SMK PKTO teachers and the 
automotive industry instructors. The objective of conducting the internal validation was to validate the model and the manual. On the other hand, the expert judgment consisted of the judgment provided by the learning experts, the material experts and the industry instructors.

The external validation, on the other hand, was conducted in the garages of Toyota,
Daihatsu and Ultratune Suzuki Gadjah Mada University (UGM, Universitas Gadjah Mada). The subjects of the study in the external validation were the students of Automotive Engineering Study Program Muhammadiyah University Purworejo. The practicum learning model for the SMK PKTO prospectiveteacher students would be displayed in Figure 1.

Table 3. The Aspects of Competence for the SMK PKTO Prospective Teachers

\begin{tabular}{|c|c|c|}
\hline No & $\begin{array}{l}\text { Indicators in the Aspects } \\
\text { of Attitude }\end{array}$ & Description \\
\hline 1 & Initiative & $\begin{array}{l}\text { When the students are provided with the problems, they } \\
\text { directly identify the problems and find the solutions. }\end{array}$ \\
\hline 2 & Discipline & $\begin{array}{l}\text { The students perform their jobs appropriately according to } \\
\text { the regulations and the job safety. }\end{array}$ \\
\hline 3 & Independence & $\begin{array}{l}\text { The students accomplish their job without depending on } \\
\text { other people. }\end{array}$ \\
\hline 4 & Responsibility & $\begin{array}{l}\text { The students perform their job until the job is finished } \\
\text { neatly. }\end{array}$ \\
\hline 5 & Cooperation & $\begin{array}{l}\text { The students accomplish their job altogether with the team } \\
\text { members and they accept the solutions if there are any } \\
\text { different opinions. }\end{array}$ \\
\hline 6 & Honesty & $\begin{array}{l}\text { The students accomplish their job according to their fact and } \\
\text { the regulations of the companies or the garages. }\end{array}$ \\
\hline No & $\begin{array}{l}\text { Indicators in the Aspects } \\
\text { of Knowledge }\end{array}$ & Description \\
\hline 1 & $\begin{array}{l}\text { Measurement tools and } \\
\text { safety }\end{array}$ & $\begin{array}{l}\text { - The students understand the measurement tools and the } \\
\text { working materials. } \\
\text { - The students understand the job safety. }\end{array}$ \\
\hline 2 & Employment & $\begin{array}{l}\text { The students understand the theories related to the job } \\
\text { competencies or the study programs. }\end{array}$ \\
\hline No & $\begin{array}{l}\text { Indicators in the Aspects } \\
\text { of Skills }\end{array}$ & Description \\
\hline 1 & Job Preparation & $\begin{array}{l}\text { The students prepare the measurement tools, the overalls } \\
\text { and the manual. }\end{array}$ \\
\hline 2 & Measurement Tools & $\begin{array}{l}\text { The students operate the measurement tools and the working } \\
\text { materials for their employment in accordance to the } \\
\text { standard operating procedures or SOP. }\end{array}$ \\
\hline 3 & Employment & $\begin{array}{l}\text { The students have the skills in accomplishing their job } \\
\text { according to the standards operating procedures or SOP. }\end{array}$ \\
\hline 4 & Processing Timeliness & $\begin{array}{l}\text { The students accomplish their job timely in accordance with } \\
\text { the standard operating procedures or SOP. }\end{array}$ \\
\hline
\end{tabular}




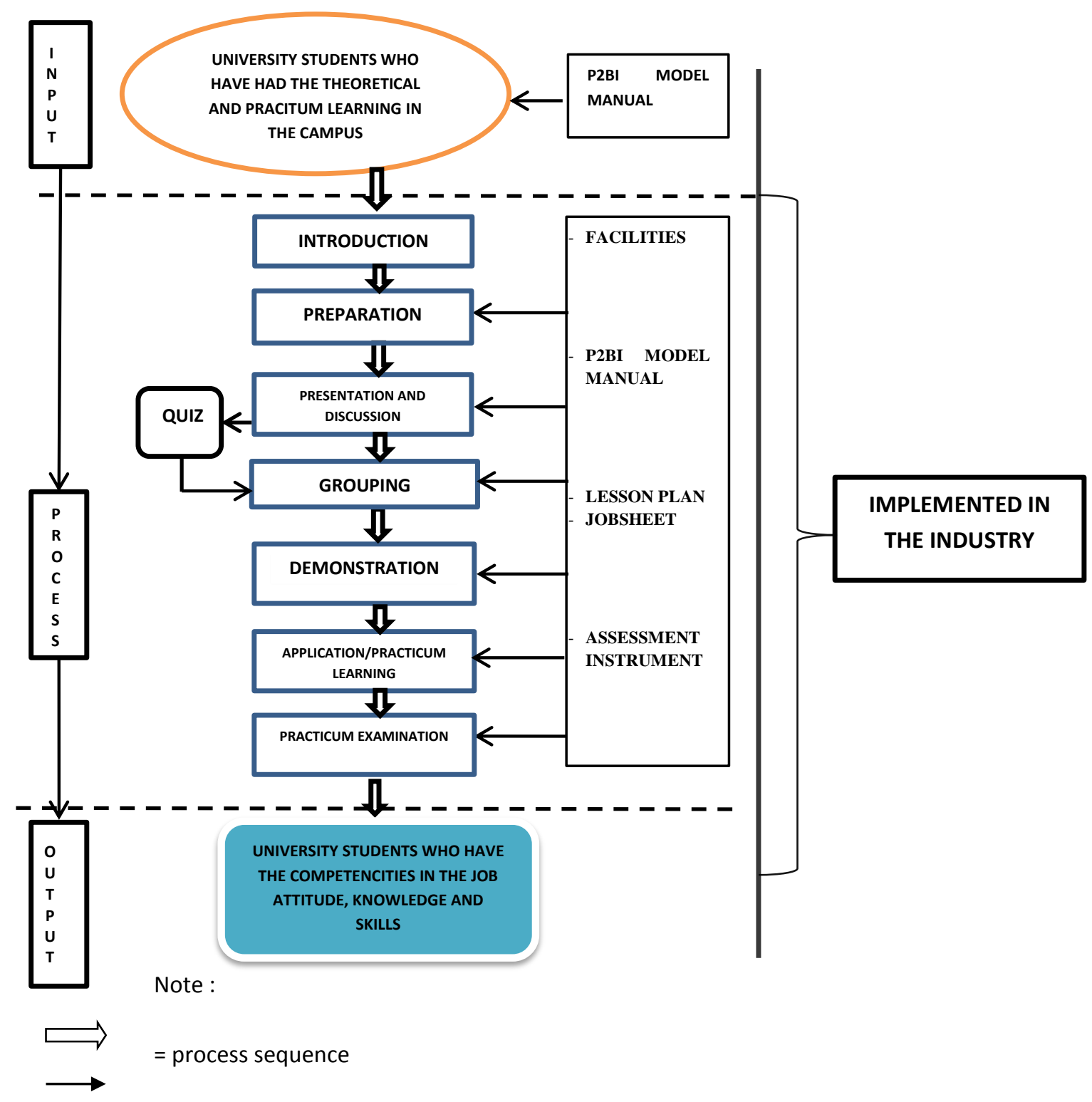

Figure 1. The P2BI Model

The P2BI Model that had been implemented toward the SMK PKTO prospective teachers might improve the competencies in the aspects of attitude that included: (1) initiative; (2) discipline; (3) independent; (4) responsibility; (5) cooperation; and (6) honesty. These aspects of attitude might developed and be implemented very well until the fifth experiment. The improvement on the aspects of attitude might be elaborated in the Figure 2, $3,4,5,6$ and 7 .

Then, the P2BI Model that had been implemented toward the SMK PKTO prospective teachers was expected to improve the competencies in the aspects of knowledge that included: (1) measurement and safety tools; and (2) employment. These aspects of knowl- edge might be developed and be implemented very well until the fifth experiment. Both aspects of knowledge might be elaborated in the Figure 8 and 9.

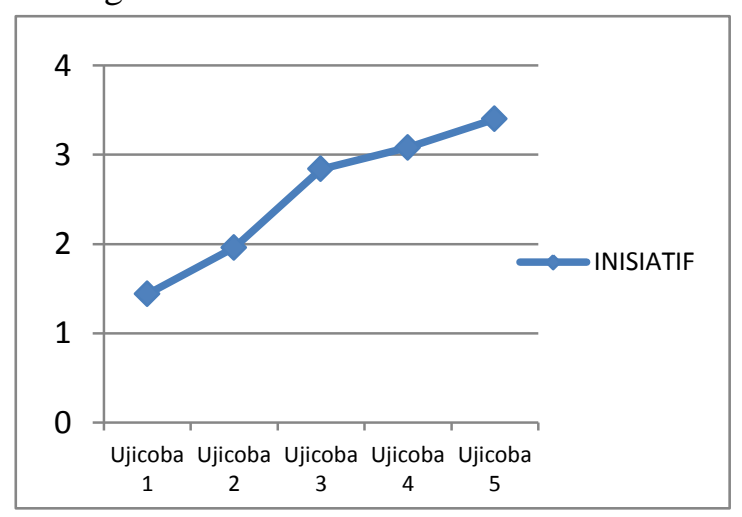

Figure 2. The Attitude of Initiative 


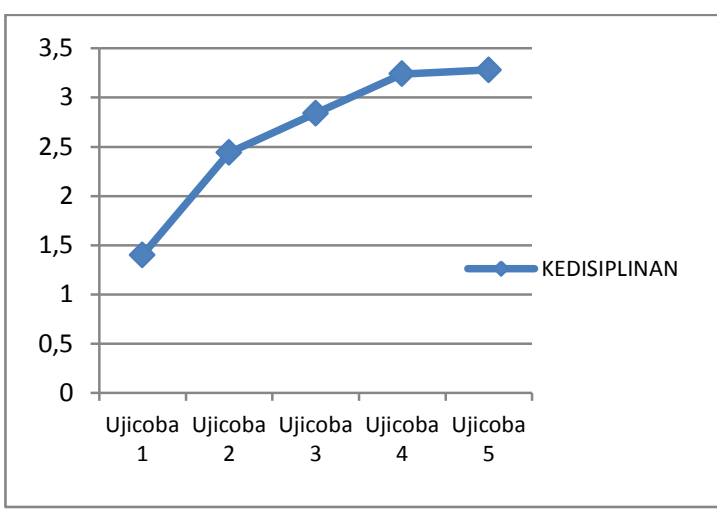

Figure 3. The Attitude of Discipline

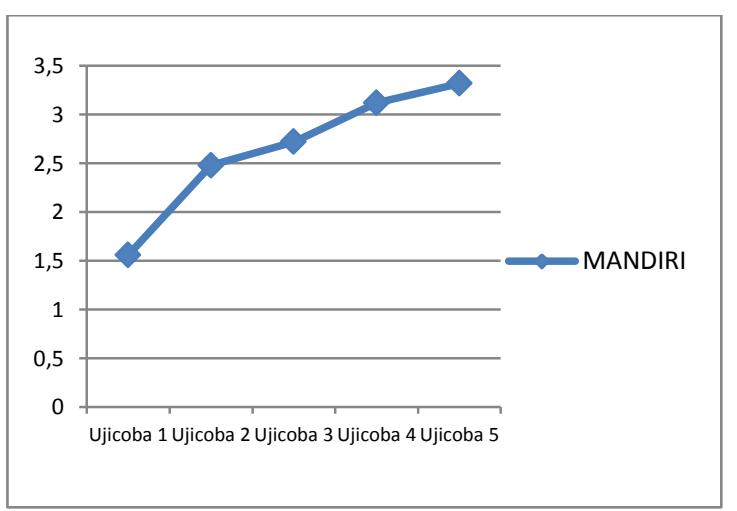

Figure 4. The Attitude of Independence

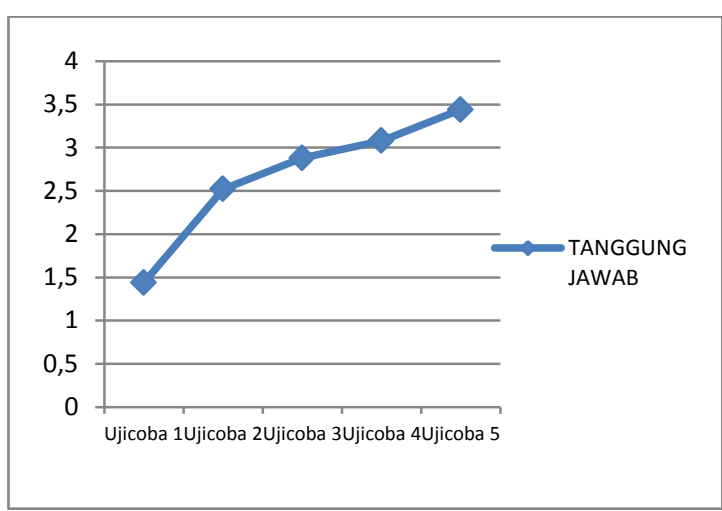

Figure 5. The Attitude of Responsibility

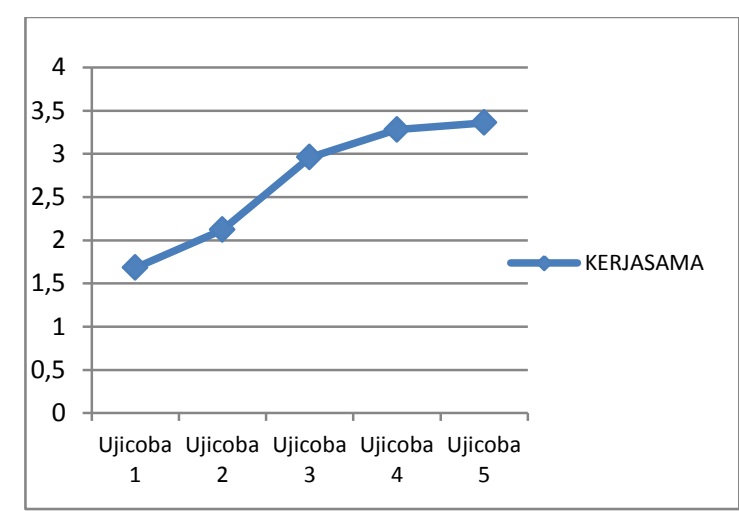

Figure 6. The Attitude of Cooperation

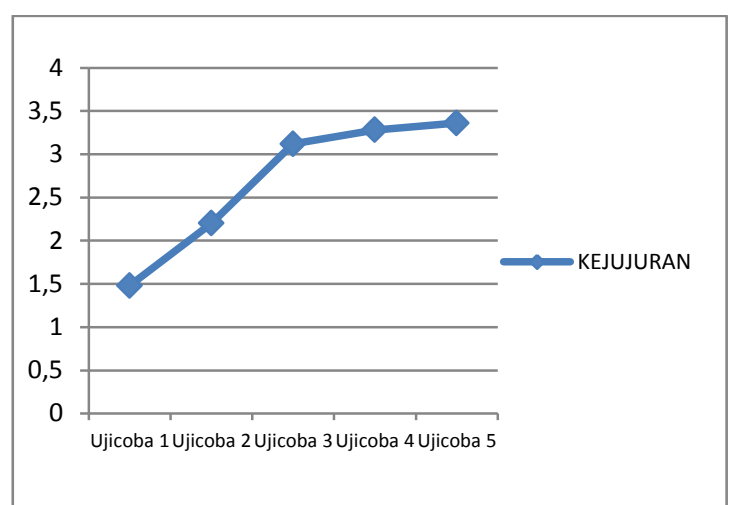

Figure 7. The Attitude of Honesty

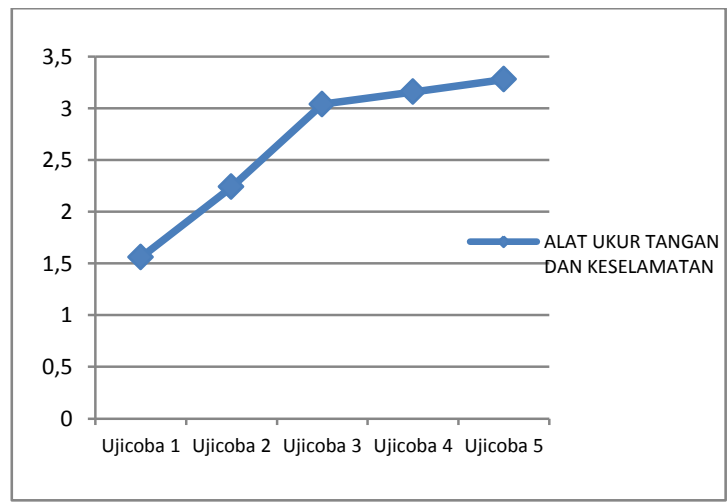

Figure 8. Knowledge of Measurement and Safety Tools

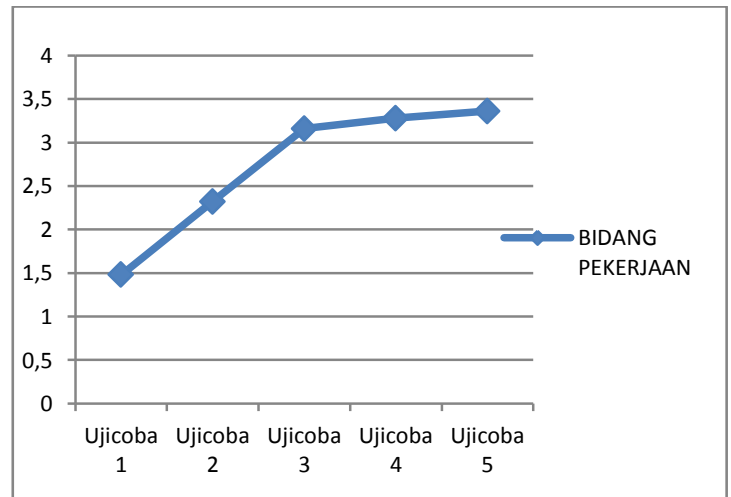

Figure 9. Knowledge of Employment

Next, the P2BI Model that had been implemented toward the SMK PKTO prospective teachers was expected to improve the competencies on the aspects of skills that included: (1) job preparation; (2) measurement tools; (3) employment; and (4) processing timeliness. These aspects of skills might be developed and be implemented very well until the fifth experiment. The four aspects of skills might be elaborated in the Figure 10, 11, 12 and 13. 


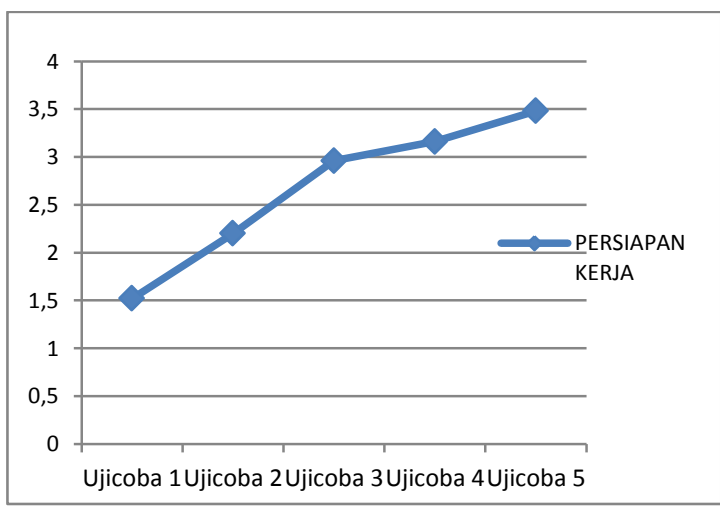

Figure 10. Skills of Job Preparation

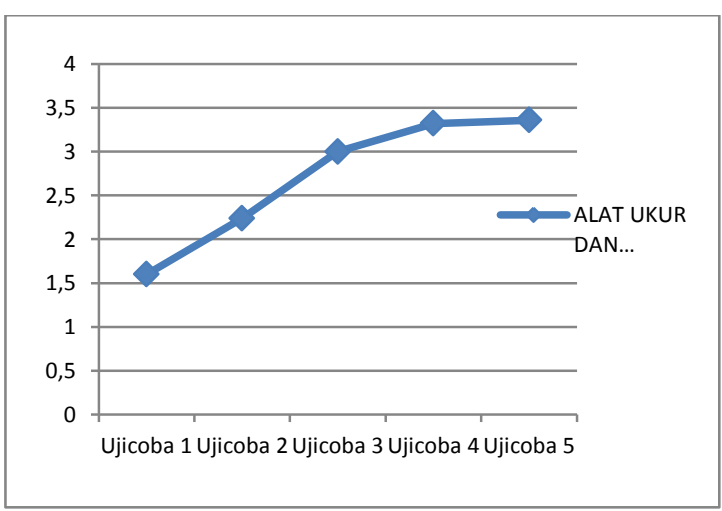

Figure 11. Skills of Measurement Tools

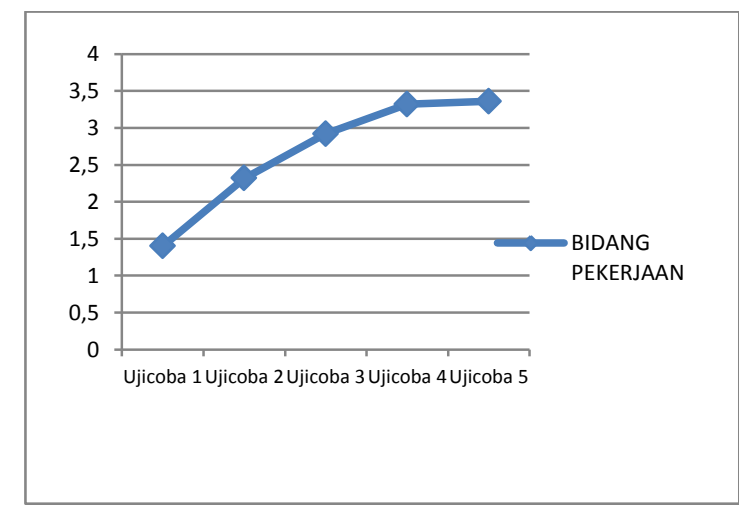

Figure 12. Skills of Employment

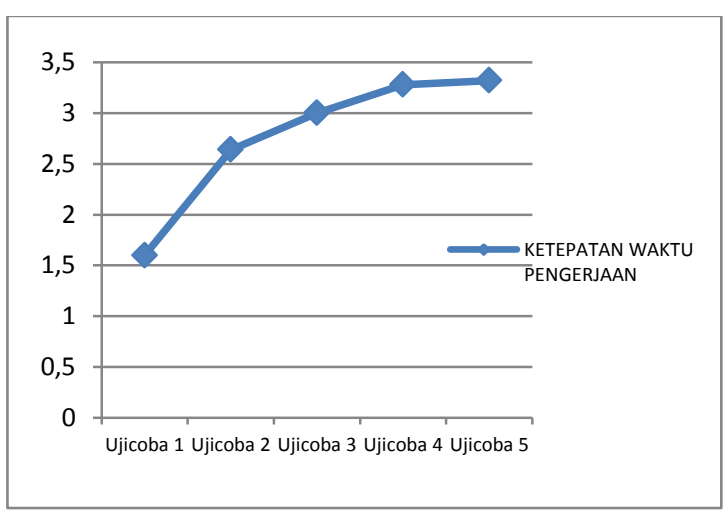

Figure 13. Skills of Processing Timeliness
The implementation of the P2BI Learning Model within five experiments showed that the results of P2BI Model might meet the criteria in the improvement of learning motivation, the aspects of attitude, the aspects of knowledge and the aspect of skills. The university students' responses toward each criterion might be described in the form of column chart on Figure 14.

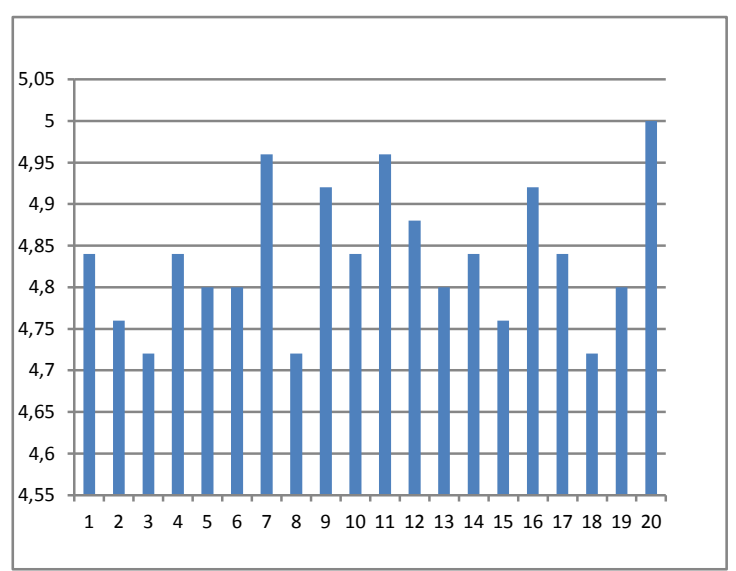

Figure 14. The Results of University Students' Responses toward Each Item

The results of P2BI Model implementation might be viewed based on the university students' activities within the model implementation. These activities were marked by the improvement on the mean of the score in the observation results toward the university students' activities within the implementation of P2BI Model experiment. The model experiment was conducted in the garage of Suzuki Ultratune UGM (the first and the second experiment), the garage of Daihatsu (the third and the fourth experiment) and the garage of Toyota (the fifth experiment). The results of observation toward the third automotive companies showed the improvement on the mean of the score on the university students' activities within the implementation of P2BI Model stages. The stages of the P2BI Model had been conducted very well by the university students.

\section{CONCLUSIONS AND SUGGESTIONS}

Based on the overall discussions, the researchers would like to draw the following conclusions. First, the aspects of the competencies that have been developed in the P2BI 
Model are the aspects of attitude, the aspects of knowledge and the aspects of skills. The aspects of attitude include the initiative, the discipline, the independence, the responsibility, the cooperation and the honesty. Then, the aspects of knowledge include the knowledge of measurement and safety tools and the knowledge of employment. Last but not the least, the aspects of skills include the job preparation, the measurement tools, the employment and the job period accuracy.

Second, the implementation of the P2BI model might serve as one of the solutions for improving the university students' quality in the practicum learning process. Such function might be proven by the increasing mean score for each aspect of competencies. The aspects of attitude (that include the initiative, the discipline, the independence, the responsibility, the cooperation and the honesty), the aspects of knowledge (that include the knowledge of measurement and safety tools and the knowledge of employment) and the aspects of skills (that include the job preparation, the measurement tools, the employment and the job period accuracy) has been equal to 3.00 in the fifth experiment and has been under the criteria of "Very Good"; the improvement has occurred in each experiment).

Third, the observation data attained from the university students' activities within the implementation of the P2BI Model stages show that the university students have implemented the stages of the P2BI Model very well. They have been able to implement the model stages appropriately without any guidance from the industry instructors. The statement has been shown by the mean score in the fifth experiment namely 3.00 .

Fourth, the results of the university students' responses toward the P2BI Learning Model have been very positive. The statement has been shown by the mean score in each question item within the questionnaires namely 4.08. The university students totally agree that through the P2BI Model they have been happier, more motivated and more serious in the learning process so that they might establish the aspects of attitude, of knowledge and of skills through the implementation of P2BI Model.

There are several suggestions that should be the focus of attention. First, the model still demands other stages of develop- ment and experiment by involving the LPTK that educates the prospective teachers, the SMK PKTO and the ATPM under the wider spectrum of automotive industry. Second, in order to make the P2BI Model more effective there should be intensive and continuous implementation in other courses.

Third, there should be similar type of study in the other domains regarding the implementation of practicum learning for the SMK prospective teachers. Fourth, the P2BI Model should be socialized in the wider target group and through the scientific forum such as seminars or research journals.

\section{REFERENCES}

Arifin, Z. (2016). Content analysis kurikulum 2014 program studi Pendidikan Teknik Otomotif (S1) jurusan Pendidikan Teknik Otomotif FT UNY. Yogyakarta: Fakultas Teknik Universitas Negeri Yogyakarta.

Chauhan, S. S. (2009). Innovations in teaching learning process. New Delhi: Vikas Publishing House.

Depdiknas. (2005). Undang-undang RI nomor 14 tahun 2005 tentang guru dan dosen.

Depdiknas. (2012). Peraturan pemerintah nomor 8 tahun 2012 tentang kerangka kualifikasi nasional indonesia (KKNI).

Dharmaputra, B. (2009). Strategi mempersiapkan guru SMK RSBI : Studi Pendahuluan di SMK RSBI DKI Jakarta 2009. In Seminar Internasional Peran LPTK Dalam Pengembangan Pendidikan Vokasi di Indonesia. APTEKINDO.

Frisk, T. (2014). Guide for the Implementation of vocational teachers' work placement periods. Helsinki: Finnish National Board of Education.

Gunadi. (2013). Peningkatan keterampilan produktif calon guru smk otomotif melalui kemitraan dengan industri. Jurnal Pendidikan Teknologi Dan Kejuruan, 21(4).

Joyce, B., Weil, M., \& Calhoun, E. (2009). Models of teaching (8th ed.). Yogyakarta: Pustaka Pelajar.

Kemendiknas. (2014) Rencana strategis 
direktorat jenderal pendidikan menengha (Renstra Ditjen Dikmen) 2010-2014.

Leighbody, G. B., \& Kidd, D. M. (1968). Methods of teaching shop and technical subject. New York: Delmar Publisher.

Linehan, M. (2008). Work based learning graduating through the workplace. Bishopstown, Cork: CIT Press.

Muhammadiyah. (2013). Analisis kebutuhan SMK teknologi untuk meningkatkan kualitas luaran dalam memenuhi pasar kerja di Sulawesi Selatan. Jurnal Pendidikan, 11(2).

Prosser, C. A., \& Quigley, T. H. (1950). Vocational education in a democracy.
Chicago: American Technical Society.

Richey, R. C., \& Klein, J. D. (2009). Design and development research. London: Lawrence Erlbaum Associates Inc.

Siriwat. (1995). APEC toward 2020: Internationalising vocational education and training. In National Conference: Internationalising vocational education and training (pp. 41-44). Sydney: NSW Board of VET.

Walker, R. J. (2013). 12 characteristics of an effective teacher. Washington: Lulu Publishing. 